УДК 93/94

\title{
ИЗОБРЕТЕНИЯ «ВОЛШЕБНЫХ ПУЛЬ» \\ В ТЕРАПИИ ИНФЕКЦИОННЫХ ЗАБОЛЕВАНИЙ: \\ ОТ ЭРЛИХА ДО ВАКСМАНА
}

Кузнецова Полина Игоревна

Алексанян Алина

Студенты

Научный руководитель: Панова Евгения Львовна

к.ф.н., доцент кафедры истории медицины Российский университет дружбы народов (РУДН)

Аннотация: Статья посвящена истории открытия антибиотиков: сальварсана, пенициллина и стрептомицина. Первым антибактериальным веществом, которое было разработано и внедрено в медицинскую практику стал сальварсан (1910), эффективное средство против сифилиса. В 1929 британским микробилогом А. Флемингом был обнаружен грибок Penicillium notatum, на основе которого 1940 году «оксфордской группой» под руководством У. Флори и Э.Б. Чейна впервые был получен пенициллин в кристаллическом виде. В 1942 году советскими микробиологами во главе с 3.В. Ермольевой было получено активное вещество из штамма Penicillium crustosum, названное пенициллин-крустозин. Первое эффективное лекарство против туберкулеза, стрептомицин, было найдено в 1943 году американским исследователем 3. Ваксманом. Открытия антибиотиков означали революцию в области лечебных технологий и привели к спасению миллионов жизней.

Ключевые слова: антибиотики, Пауль Эрлих, Александр Флеминг, 3.В. Ермольева, Зельман Ваксман

\section{INVENTIONS OF "MAGIC BULLETS" \\ IN THE THERAPY OF INFECTIOUS DISEASES: FROM EHRLICH TO WAKSMAN}

Kuznetsova Polina Igorevna

Aleksanyan Alina

Scientific adviser: Panova Evgenia Lvovna 
Abstract: The article is devoted to the history of the discovery of antibiotics: salvarsan, penicillin and streptomycin. The first antibacterial substance that was developed and introduced into medical practice was salvarsan (1910), an effective remedy against syphilis. In 1929, the British microbiologist A. Fleming discovered the fungus Penicillium notatum, on the basis of which in 1940 the "Oxford group" led by H.W. Florey and E.B. Chain were the first to obtain penicillin in crystalline form. In 1942, Soviet microbiologists led by Z.V. Ermolyeva obtained an active substance from a strain of Penicillium crustosum, called penicillin-crustosin. The first effective drug against tuberculosis, streptomycin, was found in 1943 by the American researcher Z. Waxman. The discovery of antibiotics meant a revolution in the field of therapeutic technologies and led to the saving of millions of lives.

Key words: antibiotics, Paul Ehrlich, Alexander Fleming, Z.V. Ermolyeva, Zelman Waksman

Разработчиком первого синтезированного препарата от сифилиса, сальварсана, стал немецкий химик и бактериолог Пауль Эрлих. С самого начала своей научной карьеры Эрлих активно изучал применение красящих веществ в гистологических исследованиях. В 1876 году, еще будучи студентом, он опубликовал статью, в которой отметил необычный факт избирательного окрашивания свинцом некоторых органов животных. Это наблюдение навело Эрлиха на предположение, что между химическими соединениями и тканями организма существует специфическое сродство. Впоследствии работа с красящими веществами позволила Эрлиху добиться выдающихся научных успехов в области гематологии: описать различные формы лейкоцитов, открыть тучные клетки и создать целостную теорию кроветворения с указанием значения в нем костного мозга и лимфоидных органов [2, с. 292].

С 1891 года немецкий ученый начал исследовательскую работу над применением химических веществ, способных взаимодействовать с возбудителями инфекций, к лечению болезней, вызванных этими возбудителями. Задача Эрлиха заключалась в поиске химических веществ, нейтрализующих болезнетворные микроорганизмы в тканях организма человека, не нанося при этом вреда здоровым клеткам и тканям. В качестве удобной модели для опытов он выбрал одноклеточного паразита трипаносому, который, с одной стороны, был хорошо виден в микроскоп, с другой - при его введении мышам провоцировал у них заболевание и приводил к смерти. В течение трех лет Эрлих испытал на трипаносомах более пятисот красителей. Наиболее многообещающими были эксперименты с атоксилом, производным 
мышьяка, применявшимся в то время при лечении сонной болезни, однако, вызывавшим слепоту. После продолжительных поисков была выявлена 606 модификация атоксила, которая убивала трипаносом, не нанося вреда мышам [1, с. 90].

В 1905 году немецкими учеными Фрицом Шаудином и Эрихом Гоффманом был открыт возбудитель сифилиса, названный бледной спирохетой. Гипотеза о родстве трипаносом и бледной спирохеты, которая, как позже выяснилась, оказалась неверной, подтолкнула Эрлиха к испытанию «препарата 606» на бледной спирохете. Лечение этой модификацией атоксила экспериментального сифилиса у кроликов принесло блестящие результаты.

При содействии немецкого ученого А. Бертхейма на основе химического синтеза «препарата 606» было создано новое семейство противомикробных препаратов, состоящих из трёхвалентного мышьяка. Найденное лекарственное средство Эрлих назвал «сальварсаном» [2, с. 295]. Вскоре выяснилось, что «препарат 606» вызывает некоторые побочные эффекты, что потребовало разработки его более безопасного заменителя. Еще три года поисков привели к обнаружению «препарата 914», названного «неосальварсаном», который и стал применяться для лечения сифилиса. Таким образом Пауль Эрлих создал первую в истории медицины «волшебную пулю» - эффективное и безопасное лекарственное средство от одного из самых распространенных и опасных инфекционных заболеваний [1, с. 90].

Не менее трех десятилетий прошло с момента внедрения сальварсана в медицинскую практику до создания следующего высоко эффективного антибиотика - пенициллина. Примечательно, что открытие пенициллина было сделано во многом благодаря случайности. Однажды, работая в исследовательской лаборатории госпиталя Святой Марии, британский микробиолог Александр Флеминг заметил на поверхности агар-агара в одной из чашек Петри обыкновенную плесень. Вокруг нее расположились колонии разнообразных микроорганизмов, однако, рост колонии стафилококков был значительно подавлен. Изучая этот феномен, Флеминг установил, что клетки плесневого гриба продуцируют в питательную среду активное антибактериальное вещество, позже названное им пенициллином. В 1929 году в журнале в British Journal of Experimental Pathology британский ученый опубликовал статью, посвященную своему открытию [6, с. 31].

Более двух лет Флеминг работал над вопросом промышленного производства пенициллина, однако, успеха не добился [4, с. 165]. Работа над очисткой пенициллина началась только в 1938 году «оксфордской группой» 
под руководством биохимиков Уолтера Флори и Эрнста Бориса Чейна. Использовав инновационный на тот момент метод лиофильного высушивания препаратов пенициллина из его замороженных растворов в метиловом спирте, этой группе ученых удалось получить его высококонцентрированную форму, которая отличалась высокой антибактериальной активностью и не обладала токсичностью [6, с. 33-34]. В 1940 году в авторитетном журнале «Ланцет» был опубликована статья «Пенициллин как химиотерапевтический агент», авторами которой стали все члены «оксфордской группы». В конце 1942 года, после завершения испытаний на людях, компания «Мерк» начала массовое производство пенициллина в США и Великобритании [5, с. 59].

В 1945 году Александр Флеминг, Говард Уолтер Флори и Эрнст Борис Чейн получили Нобелевскую премию «за открытие пенициллина и его терапевтического воздействия при различных инфекционных заболеваниях» $[3,4,5,6]$.

В СССР первые образцы пенициллина были получены в 1942 году советским ученым-микробиологом Ермольевой Зинаидой Виссарионовной (1898-1974 гг.) [9]. Ее заслугой явилось то, что она не только первой получила пенициллин в нашей стране (1942 г.), но и активно участвовала в организации и налаживании промышленного производства первого отечественного антибиотика в трудное для страны время [7, с. 1].

Во времена Великой Отечественной войны перед отечественными микробиологами встала задача - поиск особого вида плесени, который можно было бы использовать в качестве продуцента пенициллина [7]. Грибок искали везде, где он мог появиться. Из собранных образцов выделяли грибковые культуры и проверяли их на взаимодействие с бактериями стафилококка, которые должны были пропадать при контакте с антибиотиком. Результат пришелся на девяносто второй раз, когда из плесени, соскобленной со стен бомбоубежища, было получено активное вещество из штамма Penicillium crustosum, названное пенициллин-крустозин [8]. Целебную плесень выращивали на поверхности питательного раствора и сразу испытывали на нескольких тяжелых пациентах. Одним из первых, кого сумели вылечить с помощью пенициллина-крустозина, стал солдат с развившимся сепсисом. Эффект от антибиотика появился на шестой день после его применения: состояние больного улучшилось, а посевы крови стали стерильными [11].

Позже после открытия антибиотика Ермольева, выступая на конференциях, говорила, что работа, связанная с поиском целебного грибка, привлекла ее внимание потому, что автором этого препарата являлся Флеминг. 
На препарат пенициллина Зинаида Виссарионовна и группа микробиологов обратили внимание с начала войны, когда появились работы Флори и Абрагама [10]. Тем самым микробиолог хотела сказать, что она не претендовала на первенство, видя заслугу лишь в выделении другого активного штамма, продуцирующего пенициллин, - Penicillum crustosum.

Следующим найденным эффективным и безопасным антибиотиком был стрептомицин, который был выделен из нитевидных бактерий-актиномицетов [12]. Его открытие связывают Зельманом Ваксманом, американским микробиологом и биохимиком.

Еще в колледже он начал изучать бактерии в образцах культур, выделенных из последовательных слоев почвы. В ходе исследований микрофлоры почвы Ваксман заметил, что сложные почвенные бактерии актиномицеты, размножаясь в почве, убивали других, живущих там, бактерий. Тогда микробиолог сделал вывод, что некоторые из актиномицетов производят вещества, являющиеся токсичными для бактерий, и занялся изучением актиномицетов и их свойств. Результатом этого было обнаружение стрептомцина, чему предшествовали пять лет поисков.

В ходе исследования сотрудниками было перепробовано около десяти тысяч разных штаммов, которые могли бы продуцировать антибиотик [16]. Первым найденным веществом был актиномицин, выделенный из актиномицетов вида Actinomyces griseus. Оно убивало и микобактерий, и подопытных животных (морских свинок). Следующим антибиотиком сталстрептотрицин, оказавшийся лучше предыдущего, но терапевтически было узким: различия между лечебной дозой и смертельной были минимальны. После ряда неудачных открытий Ваксман занялся очисткой стрептотрицина, по принципу Флеминга, а исследования и поиск безопасного для человека штамма, продуцирующий антибактериальные вещества, были переданы сотрудникам [14]. На заключительном этапе этого масштабного исследования присоединился Альберт Шац, аспирант Ваксмана, которому удалось в 1943 года выделить безопасный для человека штамм Streptomyces griseus, продуцирующий антибиотик [15, с. 3]. Зельман и Альберт назвали его стрептомицин. Образец антибиотика был передан экспертам для его тестирования на безопасность и возможность использования людям. Позже стало известно, что стрептомицин является эффективным средством против туберкулеза, будучи не токсичным для разных видов животных. В 1952 году Ваксман был удостоен Нобелевской премии по физиологии и медицине: «за 
открытие стрептомицина, первого антибиотика, эффективного при лечении туберкулеза» [13].

Открытие эффективных и безопасных антибиотиков в первой половине двадцатого века - сальварсана, пенициллина и стрептомицина - привело к беспрецедентному в истории медицины прорыву в области лекарственной терапии инфекционных заболеваний. Открытие антибиотиков спасло миллионы жизней: ни один вид существовавших до этого медицинских технологий не был настолько эффективным.

\section{Список литературы}

1. Опимах И. В. Волшебная пуля, или рождение химиотерапии // Медицинские технологии. Оценка выбора. 2014. № 1. С.88-91.

2. Куриленко Т.С., Литвинов А.В. «Магическая пуля» Пауля Эрлиха // История диагностики, лечения и профилактики инфекций. 2015. № 4. С. 291-296.

3. Опимах И. В. Пенициллин и его герои // Медицинские технологии. Оценка выбора. 2015. № 2. С. 59-65.

4. Данилов А.И., Литвинов А.В. Начало эры антимикробной химиотерапии // История антимикробной химиотерапии. 2010. № 2. С. 163-169.

5. Шпилянский Э.М. Флеминг Александр 1881-1955 Шотландский бактериолог, лауреат Нобелевской премии по физиологии и медицине // Клиническая геронтология. 2013. №11-12. С.58-60.

6. Мамедов М.К., Кадырова А.А. Пенициллин, как лекарственный препарат, положивший начало новой эре развития медицины // Биомедицина. 2018. №2. C.31-36.

7. Горяная Е. Мадам Пенициллин. Академик 3. В. Ермольева разработчик способа получения отечественного пенициллина // Материалы V итоговой конференции НОМУИС в АГМУ. 2020. С. 1-4.

8. Ковалева Ю. История открытия пенициллина. [Электронный pecypc] // Режим доступа: https://tass.ru/info/2659525 Дата обращения: 10.09.2021.

9. Горшенин А.В. К истории жизни и научной работы советского микробиолога 3. В. Ермольева: историографическая характеристика постсоветских публикаций// Исторические науки и археология. 2020. №4. C. 268-271. 
10. Шерстнева Е.В. История создания советского пенициллина: вымысел и факты // Проблемы социальной гигиены, здравоохранения и истории медицины. 2019. №27(4). С. 507-512.

11. Буланов А. Панацея для фронта: как биохимики помогли выжить на войне. [Электронный ресурс] // Режим доступа: https://iz.ru/943511/aleksandrbulanov/panatceia-dlia-fronta-kak-biokhimiki-pomogli-vyzhit-na-voine - Дата обращения: 10.09.2021.

12. Паевский А. Главный «почвенник» медицины: Зельман Ваксман. [Электронный ресурс] // Режим доступа: https://biomolecula.ru/articles/glavnyipochvennik-meditsiny-zelman-vaksman - Дата обращения: 10.09.2021.

13. Boyd Woodruff H. Selman A. Waksman, Winner of the 1952 Nobel Prize for Physiology or Medicine// Applied and Environmental Microbiology. 2014. - January; 80 (1). 2-8 p.

14. Fox M. Albert Schatz, Microbiologist, Dies at 84// The New York Times. Obituary. 2005. February.

15. Rawlins M. The disputed discovery of streptomycin// The Lancet. 2012. July; 380. 3-8 p.

16. Richardson, Robert G., Underwood, E. Ashworth, Rhodes, Philip, Thomson, William Archibald Robson and Guthrie, Douglas James. History of medicine// Encyclopedia Britannica. 2020. August.

(C) П. И. Кузнецова, Алексанян А., 2021 